\title{
Alternative Product Development as Strategy Towards Sustainability in Tourism: The Case of Lanzarote
}

\author{
Christian Eckert* and Harald Pechlaner \\ Chair of Tourism / Center for Entrepreneurship, Catholic University of Eichstaett-Ingolstadt, \\ Pater-Philipp-Jeningen-Platz 2, 85072 Eichstaett, Germany \\ * Correspondence: christian.eckert@ku.de
}

Received: 28 May 2019; Accepted: 26 June 2019; Published: 29 June 2019

\begin{abstract}
Currently, tourist destinations are, more than ever, confronted with specific challenges and also negative impacts arising from overarching developments. In order to address such challenges and to reduce negative impacts resulting from tourism, sustainable development has emerged as a widely accepted approach. Under special consideration of seemingly successful destinations, this article aims to identify complementary strategies towards sustainability in tourism, instead of developing completely new strategies which replace the existing ones. This will be done in the course of endogenous values and structures within a destination. To discuss this issue, the Canary island of Lanzarote is used as case in point, via a qualitative interview series consisting of eleven interviews with different direct and indirect tourism stakeholders from the island, which have been evaluated according to the GABEK ${ }^{\circledR}$-method (German abbreviation for "GAnzheitliche BEwältigung von Komplexität": holistic coping of complexity). The results show that aspects of mass tourism have a negative impact on the island and therefore a seemingly successful destination, at least in quantitative terms, is confronted with issues of sustainability and a need for action. In this field, diversification regarding both new offers and target groups is helpful to enable tourism and regional development to be more sustainable. In consequence and from a conceptual point of view, alternative product development as a new approach towards sustainability in tourism within established destinations will be presented.
\end{abstract}

Keywords: tourism development; Lanzarote; sustainability; alternative product development; strategy

\section{Introduction}

Tourism development currently takes place in an extremely dynamic and competitive environment [1]. In the course of expanding transformative environments and framework conditions regarding both supply and demand, tourist actors are confronted with the question about how to act appropriately. Such current developments can, for example, take place in emerging discussions about overcrowding and over-tourism, changes in tourists' values, increased demand for sharing economy offers, and new opportunities in the field of mobility [1-9]. Therefore, challenges in tourism generally require specific strategies and plans for action $[10,11]$ in order to efficiently use available potentials for development [1]. Since the developments mentioned above affect urban and rural destinations equally, which in both cases represent the living space for the local population [12], one crucial element for success can be identified in sustainable tourism development [13].

Under special consideration of seemingly successful destinations, this paper aims to discuss how complementary strategies towards a more sustainable tourism development can be formulated on the basis of local values and structures within a destination, instead of developing completely new strategies which replace the existing ones. Since especially island destinations are confronted with 
specific challenges regarding tourism development $[14,15]$, this will be achieved via an examination of the island of Lanzarote, which is located in the Canary Islands-archipelago. The island of Lanzarote is highly relevant as place of research, due to steady discussions about tourism development and growth [16] and the islands character as an experimental zone for sustainable tourism in the context of an overflowing capacity of tourism growth [17]. Against this background, it is important to note that the island has received a strong increase in tourism numbers in the last years: between 2010-2018, tourist arrivals on Lanzarote have grown from 1,889,322 (2010) to 2,880,051 (2018), which means an increase of $52 \%$ within a period of eight years [18]. With regard to added value resulting from tourism, in 2017 tourists had an average expenditure of $134.14 €$ each day, of which an average of $97.97 €$ respectively $73 \%$ was paid in the place of residence, and $36.17 €$ respectively $27 \%$ remains in the Canary Islands [19].

Against the background of the described problem statement in general and on Lanzarote in particular, the strategy of alternative product development will be introduced as a complementary strategy towards a more sustainable destination development, which is based on endogenous potentials within a destination. With regard to the structure of the article, subsequently to a literature review on sustainability within tourism development, the concept of strategic product development as a strategy for destination development will be presented. After a description of the methodological approach, the results will be presented. These serve as the groundwork for the subsequent discussion on alternative product development as a new strategy, which is derived from the concept of strategic product development.

\section{Literature Review}

\subsection{Sustainability within Tourism Development}

It is widely accepted that tourism has the capability to make a positive contribution to urban and regional development and, in consequence, to improve local economies and/or the living conditions within a certain area $[20,21]$. However, tourism can also result in negative impacts [22-28], which then have to be addressed actively by the involved actors due to the circumstance that tourism tends not to self-regulate [29,30]. Negative effects resulting from tourism can be observed on four different levels in a destination, namely: (1) economic well-being, (2) social well-being, (3) cultural well-being and (4) environmental well-being [26]. To address negative impacts on these four levels, the concept of sustainability has gained a strong interest in tourism development during the last two decades [31-34] and hence became "a cornerstone of quality and competitiveness in tourism" [35]. In other words, sustainable tourism is today "almost universally accepted as a desirable and politically appropriate approach to tourism development" [29].

Quite generally, it can be stated that sustainable development assumes the view that development should occur in line with the needs of current generations while maintaining the present conditions and opportunities also for future generations [36-38]. Considering this in relation to tourism, it can be stated that a solid basis for the discussion of sustainability and tourism is marked by the distinction between (1) sustainable development in the context of tourism and (2) sustainable tourism [39,40]. On the one hand, sustainable development in a tourism context can be seen as tourism, which allows sustainability in a certain destination for an indefinite period. On the other hand, the term sustainable tourism can be defined as "tourism which is in a form which can maintain its viability in an area for an indefinite period of time" [39]. Moreover, sustainable tourism ideally reflects a holistic approach for development, which is based on sound economic, ecological and socio-cultural principles [41-44]. In consequence, sustainable tourism is able to provide economic benefits from tourism, while both the ecological and socio-cultural integrity of a destination is preserved [45].

With the aim to "support the continuous improvement of sustainability and resilience in the tourism sector through systematic, timely and regular monitoring of tourism performance and impact and to connect dedicated destinations in order to better understand destination-wide resource use and 
foster the responsible management of tourism" on an international scale, the United Nations World Tourism Organization established the International Network of Sustainable Tourism Observatories (INSTO) in 2004 [46]. Within this framework, six central fields of action are examined with the aim of reaching sustainable development, as can be seen in Figure 1 below.

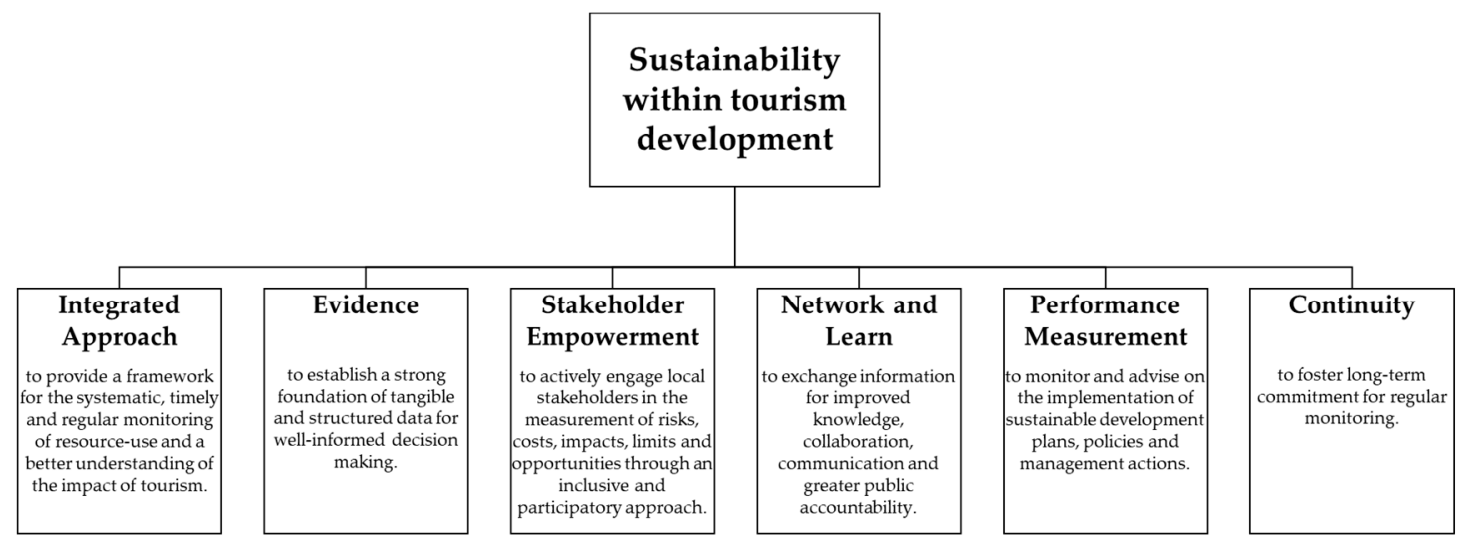

Figure 1. Objectives of sustainability within tourism development (Source: own illustration, based on Reference [46]).

As becomes apparent from Figure 1, one important factor in sustainable tourism development is marked by the empowerment and involvement of a broad range of heterogeneous stakeholders [39,47-50]. Related to this, various studies have named relevant actors and discussed their role within the process of sustainable tourism development $[39,47,48,51-54]$. Within this field, five central stakeholder groups can be named: (1) members of the local community, (2) tourism industry representatives (e.g., from local entrepreneurs to international tour operators), (3) policy makers (e.g., local government within a destination), (4) administrators (e.g., destination management organization) and (5) external experts (e.g., consultants) [55-58]. While the first four can especially make contributions due to their expertise in local circumstances, the last group can be helpful in the area of more independent and objective advice based on experiences from other destinations [55]. One prevalent strategy within this sphere of tourism development can be identified in the process of strategic product development, which will be presented below.

\subsection{Strategic Product Development}

In the context of tourism development, the resource-based view marks a widely accepted approach based on the endogenous potentials of a destination [59-65]. Within this sphere, one specific strategy is marked by the process of strategic product development, which focuses on location-specific core competencies, values and themes, from which appropriate products and offers can be derived, as is also illustrated in Figure 2 [66,67]. 


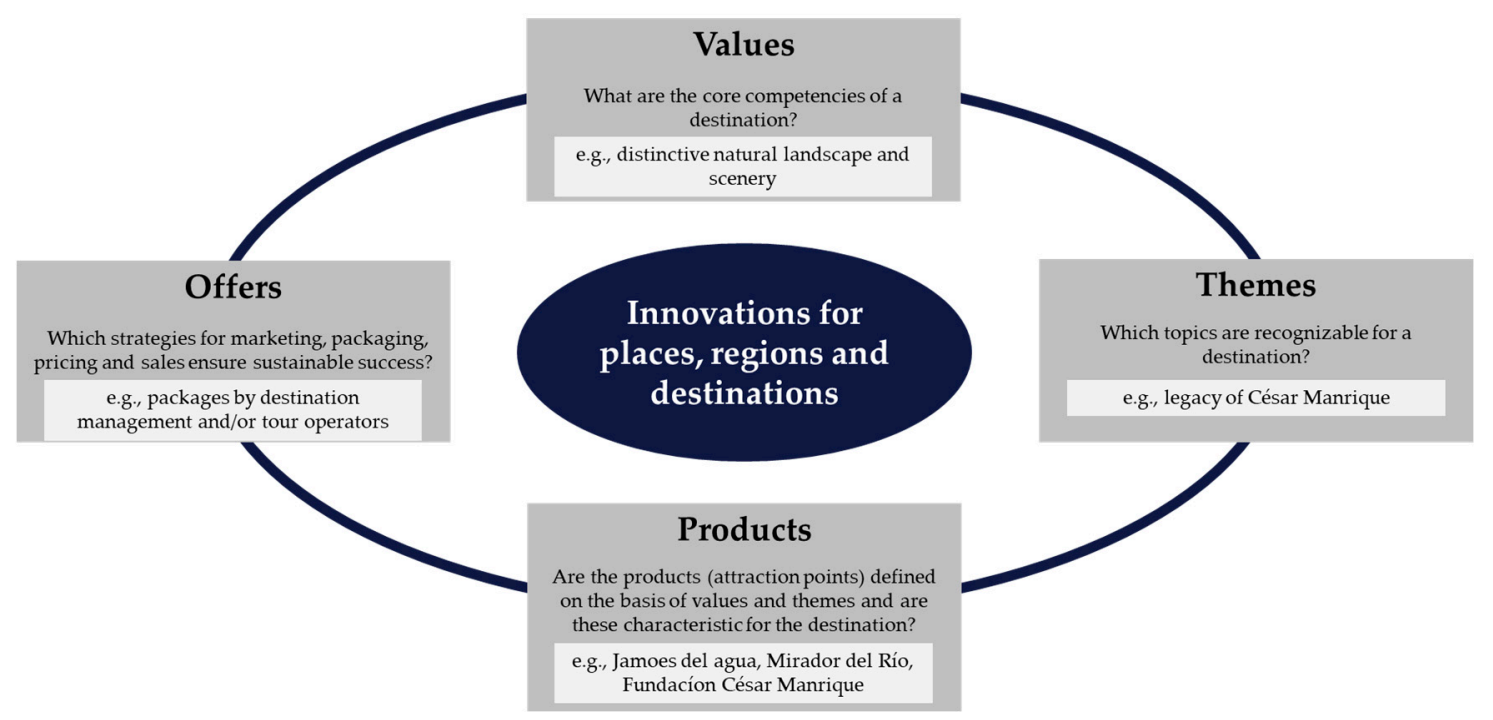

Figure 2. The process of strategic product development (Source: own illustration, based on References $[66,67])$.

The starting point of this process is marked by the identification of an endogenous value basis, which is distinctive for the considered destination. This means that, according to the resource-based view, destination-specific values and core competencies have to be figured out. This elaboration, which should be supported by a broad range of relevant stakeholders within the destination, builds the foundation for both destination-specific and innovative product development. Based on these identified values, suitable and characteristic themes (by means of which a destination can be recognized) have to be derived in a second step. Once destination-specific values and themes have been assessed, products based on the first two steps can be developed. Such relevant products should be embedded in both a sustainable and an overall concept, which links single destination-specific products to each other, in order to provide an appealing overall experience to the customer. The final step is marked by the implementation of the products within the market via suitable offers. Here, the focus lies with the question of target group-oriented distribution strategies, whereby it is important to emphasize that target groups may not only consist of foreign visitors, but also of the local population [1,66,67].

In order to make the process of strategic product development even more comprehensive, it will be demonstrated exemplarily in the context of the island of Lanzarote, whereby the examples for each step are already integrated in Figure 2: due to the exposed location of the Canary Islands-archipelago in the Atlantic Ocean, a distinctive feature of Lanzarote is a relatively high number of hours of sunshine, which is accompanied by mainly constant temperatures throughout the whole year and special climatic conditions. The combination of these factors can be seen as a baseline for a distinctive natural scenery and landscape, both of which provide a special value for the island. This setting was used by Canary Island-native artist César Manrique as a kind of playground, as he integrated his art directly into the landscape of the island. In addition, he was strongly committed to the preservation of these conditions by establishing a so-called "intelligent tourism". Despite his death, these efforts still give him a strong presence on the island, as well as in the collective consciousness of the local population. Therefore, César Manrique can be seen as one of the island's themes, which can be applied to the destination's product development. At the product level, this theme can be presented via the integration of the artworks of César Manrique into the landscape, such as his works Jameos del agua or Mirador del Río. Moreover, the César Manrique Foundation's information center can be seen as a touristic product, which communicates the artist's ideas and convictions to visitors. In a fourth and final step, such products can be implemented in the tourism market through special offers, for example via the island's destination management organization, but also through private tour operators. 


\section{Methodology}

In the context of the study, a qualitative research design was developed in order to identify and analyze opportunities towards a more sustainable tourism on Lanzarote. To reach this aim, relevant actors in both direct and adjacent areas of the island's tourism have been identified in a desktop research prior to the stay on site, which took place in the first half of the year 2018. In this course, 21 potential interviewees had been requested, and a total number of eleven on-site interviews with a deliberately open character was conducted. The interviewees themselves were located in the fields of politics and tourism administration, heritage development, as well as cultural and natural attraction points. Moreover, interviewees had their background in the areas of gastronomy and real estate, and also infrastructure development. In general, a tendency towards a rather low willingness to participate in the study had to be observed in this context, with most requests being made several times. This can be attributed, among other things, to the fact that the topic is a quite sensitive one and was discussed at a time when discussions about over-tourism and critical effects of steady tourism growth were gradually expanding to a broader level.

The interviews themselves usually had a duration of about 45-60 minutes. In addition to an introducing discussion of the recent development of Lanzarote in general and the role of tourism in particular, the further content of the interviews revolved around the local attitude towards tourism development. In this regard, it was also discussed how the local population is affected by the tourism industry and to what extent it benefits from the created added value. The role of César Manrique and his erstwhile demands for the so-called "intelligent tourism" was another topic of conversation. Facing the current structures on Lanzarote, the extent to which César Manrique's considerations are currently rather a hindrance or a suitable approach towards tourism development in general and sustainable tourism development in particular was another topic discussed. With a view towards the future of tourism development, it was also discussed which possible paths exist for the further development of Lanzarote as both attractive living space for locals and tourist destination, and how such paths can be shaped in a sustainable way.

The open design of the interviews, which has already been mentioned above, was based on the fact that the study was conducted according to the principles of the GABEK ${ }^{\circledR}$-method (the German abbreviation of "Ganzheitliche Bewältigung von Komplexität": the holistic mastery of complexity) and then evaluated using the accompanying software WinRelan ${ }^{\circledR}$. This procedure makes it possible to reduce normal language verbal data in terms of complexity and to visualize it in form of linguistic conceptual networks [68]. Therefore, it was necessary to take an audio-record of the interviews and to transcribe them afterwards. Based on the then prevailing text documents of the interviews, a lexical coding of each interview can be performed using WinRelan ${ }^{\circledR}$. In consequence, the software is able to identify semantic relationships in the sum of all interview statements. These relationships can in a next step be reduced in terms of complexity and afterwards visualized in the form of network-graphs [68]. In a compressed way, these network-graphs present the central topics and associations of all interviews and show the interlinkages between them. In this context, GABEK ${ }^{\circledR}$ is able to demonstrate cooperation relationships in the course of regional and destination development based on joint-solving approaches [69], which underlines the suitability of this method for the prevailing research. In a compressed way, the following Figure 3 illustrates the most central steps within the working process in the course of GABEK ${ }^{\circledR}$, respectively in relation to WinRelan ${ }^{\circledR}$. 

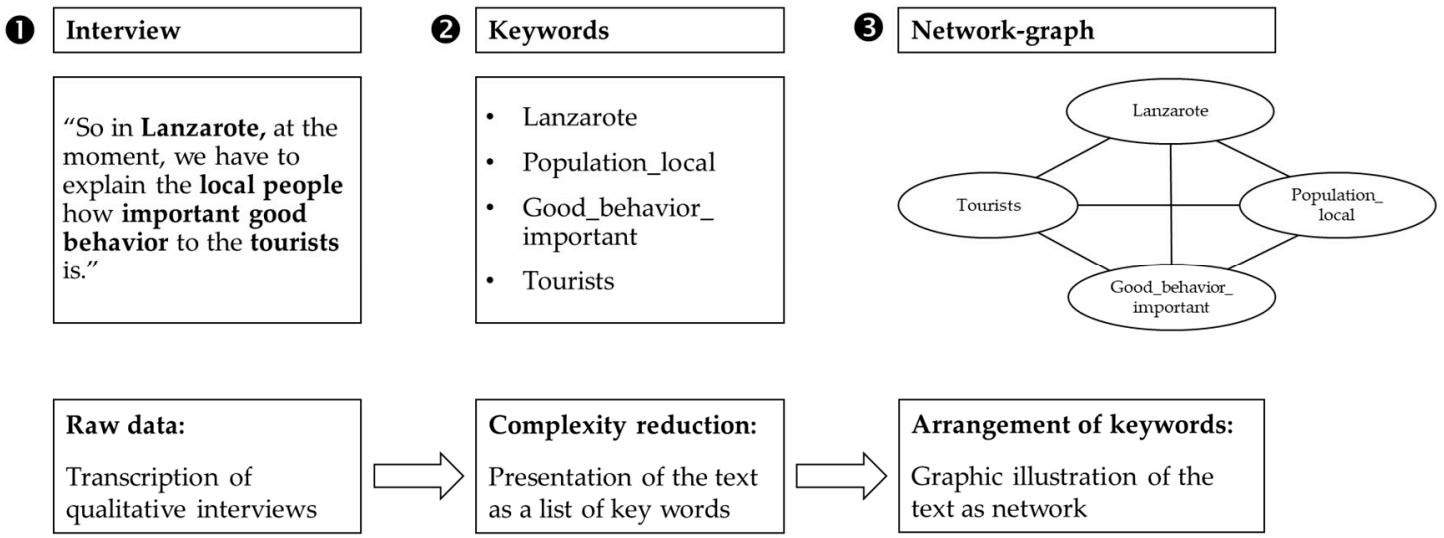

Figure 3. Process within the method of GABEK ${ }^{\circledR}$ by using the software WinRelan ${ }^{\circledR}$ (Source: own illustration).

\section{Results}

This section aims to present the results of the empirical survey. After a general presentation of the central associations concerning Lanzarote, the island's tourism development will be revealed. This is followed by a third network-graph focusing on low cost tourism and subsequently future development paths for Lanzarote.

\subsection{Lanzarote: Central Associations}

Regarding the most central associations of the interviewees with the island of Lanzarote, the results suggested two superordinate thematic clusters, as well as some additional singular topics, as Figure 4 below shows: the two clusters contained, on the one hand, specific and interrelated keywords describing the characteristics of Lanzarote in general, and on the other hand, aspects related to tourism in Lanzarote in particular. A complementary characteristic (which can be transformed into a sort of keyword) was, in addition to aspects related to sports, also the volcanic origin of Lanzarote within the broader context of the neighboring islands of the Canary Islands-archipelago, which is located in the Atlantic Ocean.

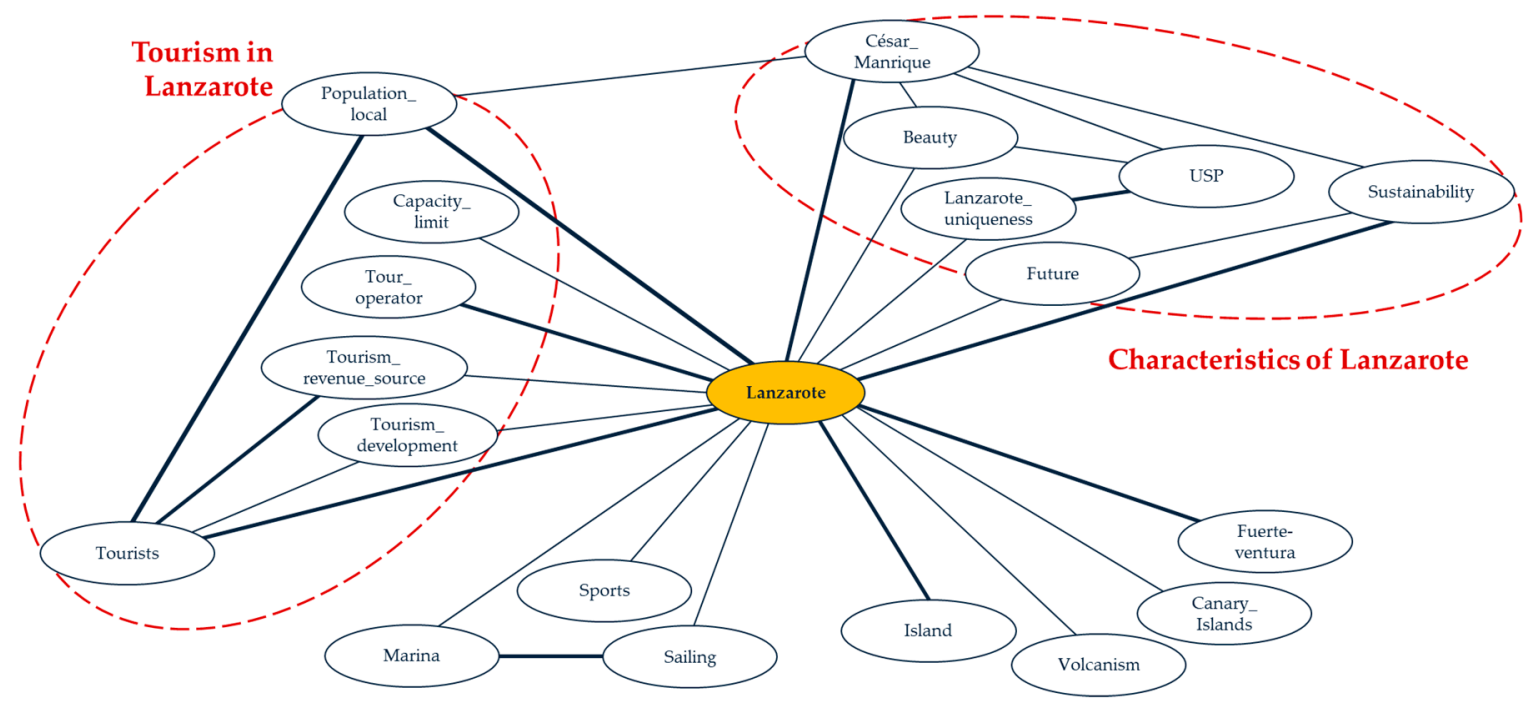

Figure 4. Network-graph “Lanzarote” (Source: own illustration, based on WinRelan ${ }^{\circledR}$ ).

In the context of the first thematic cluster, which described rather general characteristics of Lanzarote, certain keywords located between the island itself, sustainability and César Manrique seemed to play an important role for the interviewees. In this field, César Manrique, who attributed a 
distinctive character and certain beauty to the island and tried to develop this into a unique selling proposition, can be regarded as an important actor within the development of Lanzarote. This seems to encourage efforts to educate and sensitize the local population to the place they inhabit, since the island is seen as a unique place by the interviewees. In a wider context, these erstwhile efforts by César Manrique and his claim for an intelligent tourism can therefore be seen as the origin for a holistic, sustainable and future-oriented development, which also paved the way for calls for a sustainable tourism model, as the following interview quotations point out:

"[César Manrique] told the people: Listen, what you are doing here is incredible special, you grow wine on a climate where there is no rain. What you are doing is special, and it is particular to here. And this island has a great capacity for tourism. And [César Manrique] helped the people to understand that this space was special. That we are very lucky to live here, but we need to protect it." (Interviewee 1)

"In the end César [Manrique] achieved the acceptance of a sustainable tourism model on the island, which lasted for many years. And he developed different places on the island, which define this uniqueness until today. However, for him it was always important to see Lanzarote as a whole, and not tolerate only on single places. This was his legacy." (Interviewee 4)

Regarding the more tourism-specific cluster, the results showed an overarching relationship between tourists on the one hand and the local population on the other. It became apparent that there was no direct linkage between the two keywords "tourism development" and "tourism revenue source" to the local population. This means that, according to the interviewees, tourism development, and thus the tourism industry, though providing a source of income, does not provide a well-developed relationship to the local population, which will be described in more detail in the upcoming network-graph focusing on tourism development. It rather appears that international tour operators seem to dominate tourism and its structures on Lanzarote, since they attract a large number of tourists, e.g., through all-inclusive packages. Although the term "over-tourism" does not seem appropriate in the context of Lanzarote, there are discussions about a slowly but surely already-reached capacity limit, as the following quotations demonstrate:

"The island has more tourism now than ever! The tourists are falling out of the sky, this never ever happened like that. Lots and lots of different systems and dynamics have converged to make this the most profitable time ever for the island." (Interviewee 1)

"We see, if we put the focus on growing, having more tourists, at the end of the day this is the catastrophe for the destination." (Interviewee 2)

These first results and central associations in the context of Lanzarote, the island's tourism and César Manrique provide a broader framework in which tourism development occurs, which will be presented more detailed in the following section.

\subsection{Tourism Development on Lanzarote}

With regard to tourism development on Lanzarote, the empirical results showed three major thematic clusters, which evolved around local structures, potentials for further development and fields of tension, which can be either already existing or simply possess potential (see Figure 5). 


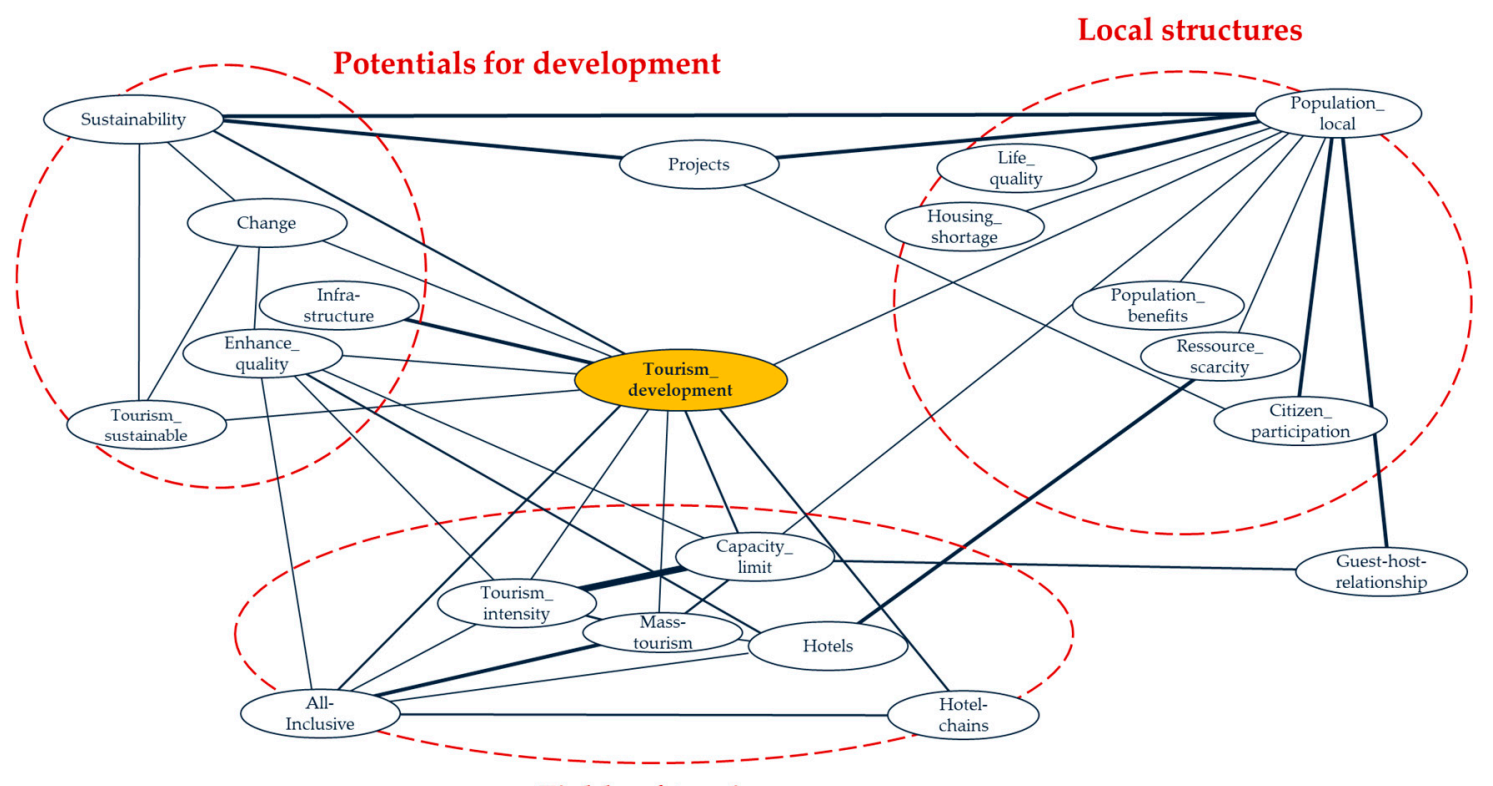

Fields of tension

Figure 5. Network-graph "tourism development" (Source: own illustration, based on WinRelan ${ }^{\circledR}$ ).

Considering tourism development and local structures, the results showed a direct superordinate relation between tourism development and the structures on Lanzarote. However, in this field the subordinate local structures were interestingly rather connected to the local population in particular than to tourism development in general, since such direct linkages are missing in Figure 5. For example, there seemed to be neither a direct relation between the island's tourism development and the quality of life, nor between the benefits for the local population and tourism development in Lanzarote. Moreover, it appeared that issues like a certain lack in the availability of resources were rather directly an issue for the local population on Lanzarote and not for tourism development as such.

"[ ... ] because this is a tiny island, resources are limited. And we have no water for everybody, unfortunately. Sometimes, I don't have water in my house, but tourists always have water in their hotel. I think that's not fair!" (Interviewee 5)

This quotation connects the bridge to certain fields of tension with regard to tourism development on Lanzarote, which evolve around an apparent dominance of hotel chains and all-inclusive packages. With regard to the scarcity of resources that has been mentioned by the interviewees, hotels in general and hotels connected to international tour operators in detail seem to play a crucial role. For the interviewees, developments like these can be seen as a cause for problems related to the phenomenon of mass tourism. This results in high tourism intensity and a slowly-reached capacity limit for tourism on Lanzarote. The issue of capacity limit especially seemed to have an influence on the local attitude towards tourism and, in consequence, the both the current and future quality of the relationship between guest and host:

"Tourists come with all-inclusive in the hotel and they go from the airport to the hotel and they don't visit anything [on the island]. Just sitting at the swimming pool all day, because it is all-inclusive. And afterwards, they go to the airport, they go back home." (Interviewee 10)

"We are [currently] for example at over $90 \%$ occupancy, which is almost at the limit of the island." (Interviewee 3)

"There was a time when the contact between tourists and locals was very good, but now that's not the case anymore. It is not a conflict yet, but they are moving towards it." (Interviewee 4) 
Despite some fields of tension, the results also showed that the interviewees identify potentials for future development, which were embedded into a broader framework of sustainability in general and sustainable tourism in particular. These potentials can be seen, among others, in an enhancement of the provided service quality, for example in the fields of accommodation, mobility or even safety. In sum, all these factors contribute to the overall tourist experience. While the results also show that a certain need for action is recognized, it must be emphasized that this quality enhancement does not seem practicable in the context of single and short-term measures, but rather within specific projects during a long-term process.

"[In the past,] they just wanted the numbers: more airplanes, more hotels, more and more numbers [ ... ]. And that's where the worry starts: we are going to try to get better quality! You have to do it by renovating accommodation, improving the infrastructure, the security, the experience, educating all the workers, bringing the hygiene up to a certain level, and bit-by-bit the prices start to increase. But it doesn't happen overnight." (Interviewee 3)

Since Figure 5 has already demonstrated a superordinate field of tension in the range of hotel chains and all-inclusive hotels, the following section focuses on a deeper examination of a so-called "low-cost tourism," which seems to a have a certain dominance within the tourism structures on Lanzarote.

\subsection{Low-Cost Tourism on the Island of Lanzarote}

Analogous to the previous remarks, a thematic clustering within the next network-graph was also possible with regard to interviewees associations concerning low-cost tourism. In particular, these are abetting factors for the emergence of low-cost tourism, changes on the demand-side, resulting tensions and also some general consequences, as can be seen in Figure 6.

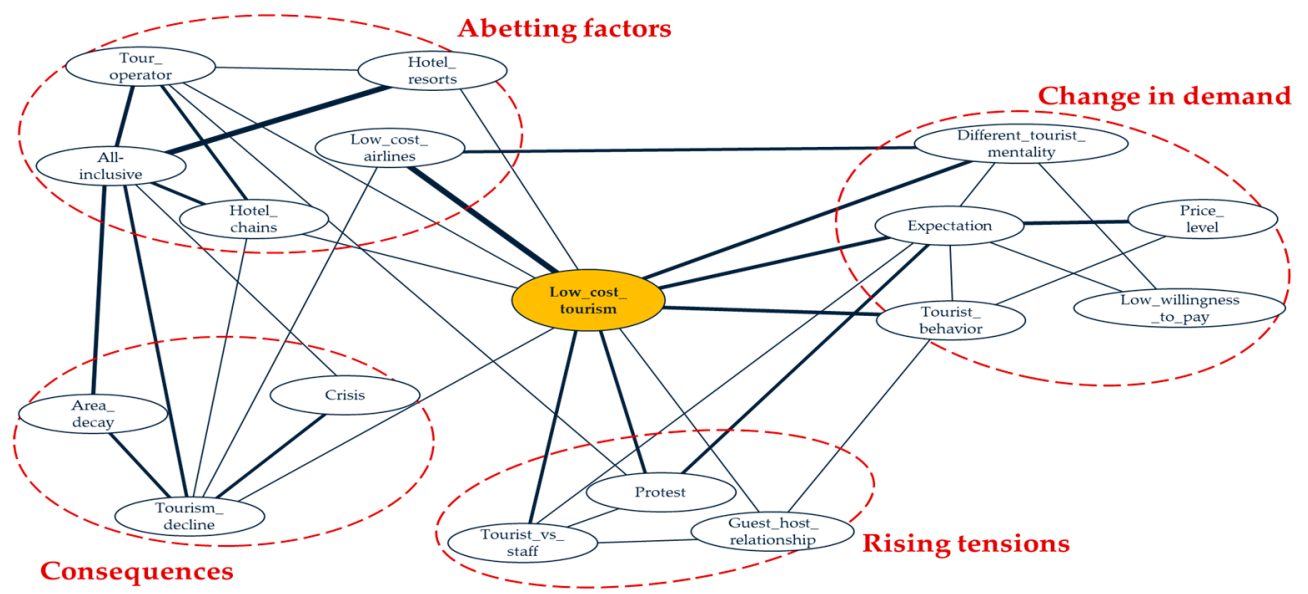

Figure 6. Network-graph “low-cost tourism” (Source: own illustration, based on WinRelan ${ }^{\circledR}$ ).

With regard to abetting factors for the emergence of low-cost tourism, the aforementioned aspects of hotel chains and resorts seemed to have a certain impact, as well as an apparent dominance on all-inclusive offers from tour operators, which was supplemented by the presence of low-cost airlines. A particularly strong connection exists here between hotel resorts and all-inclusive offers, which means, according to the interviews, that a substantial part of the added value does not remain directly on the island. Instead, this revenue mostly is transferred to international tour operators located outside the island, mainly in continental Europe. In consequence, this means that international tour operators seem to put a high pressure on the island of Lanzarote due to their position within the market situation.

"The all-inclusive model, the big hotel model, does not leave a lot of money on the island. What it does, though, is creating employment, and legal employment where people have contracts. They employ a lot of people, these hotels. So, from that point they do help the 
economy. But from the local business person, who has a shop on the street, from that point, they do not create a lot." (Interviewee 3)

"The problem here lies on these people who spend their money not in the destination, but in the home country. Because these all-inclusive hotels are normally managed by tour operators which are not located on the island. So business is not here, it is outside." (Interviewee 5)

However, such structures are, of course, only possible if the customers have a sufficiently critical demand for all-inclusive offers and packages built by international tour operators. In this regard, the results show that there has been a change in customers' mentality in the past, which seems to come along with a high price sensitivity on the demand side. Paradoxically, the guests' high expectations regarding the overall tourist experience interestingly seem not to be affected by this high price sensitivity. Instead, tourists seek for high quality experiences sold for best affordable prices.

"This can be seen especially if you go to the three tourist centers. [Tourists] come here and leave no penny. That means most of them barely get out of their [hotel], they paid three meals a day, and then all the snacks are added. And if they ever come out then they will do a bus tour [... ]. But let's say individual tourists leave more money here than these mass tourists." (Interviewee 9)

"The mentality of the people [has changed]: it cannot cost anything more, they want everything, but it should not cost anything. But on the other side they feel like a guest, they want to be treated like a king. All the tourism here, all the people who come here are not the same people than before." (Interviewee 8)

According to the interviews, perceptions like these result in rising tensions between tourists and the local population and are partly enforced by the partly negative behavior of some tourists. In consequence, this might lead to a reduced tolerance at the local side and thus a decline in the quality of the guest-host relationship and hospitality. In order to avoid such a decline and maintain the island's hospitality, a certain control of both quality and quantity in tourism seems to be necessary.

"The locals are very hospitable. But sure, there comes a moment where you feel uncomfortable and restricted. We can remain hospitable, but with limited capacity, that's the key. Tourism is good and important, but in a limited and fragile area like this, it just has to be controlled. And this is not only for Lanzarote, but for every tourist destination. We can currently see that in some major European cities which conflicts mass tourism brings with it." (Interviewee 4)

Since a functioning relationship between guest and host is a crucial criterion for the attractiveness of a destination, a decrease in hospitality resulting from low-cost tourism can also have further negative consequences, if, for example, tourists shift to other destinations with a similar offer. This may initially lead to a decline in tourism intensity, which—due to the island's dependency on tourism-in consequence can lead to a certain overall crisis for the island.

"There's very little else on the island to provide an income for the local people. So yes, in the downturns when you see the-not revolts—-but the real problems, people's attitudes towards tourism in the downturn. In the upturn, I think, most people are benefitting, so most people are happy. But, it's very dynamic, very, very complicated to keep an island like this. Constantly developing, constantly growing, creating more wealth, but at the same time sustaining it aesthetically, sustaining the infrastructure and keeping the quality of the tourism: this is very hard to balance." (Interviewee 3)

These observations and an obvious certain need for action in order to design more sustainable tourism on Lanzarote lead to some possible paths for further development, which will be demonstrated in the following. 


\subsection{Future Development Paths}

Even though there seem to exist some crucial challenges, the results also provided perspectives for future development paths on Lanzarote. Next to both tourism and regional development, these paths affect also issues in the field of resources and mobility and have to be embedded into political considerations and structures, as Figure 7 illustrates. It is important to emphasize that such developments and efforts towards a more sustainable regional and destination development should occur with the active involvement of the local population by the island's government (Cabildo), for example in the form of long-term education and specific projects.

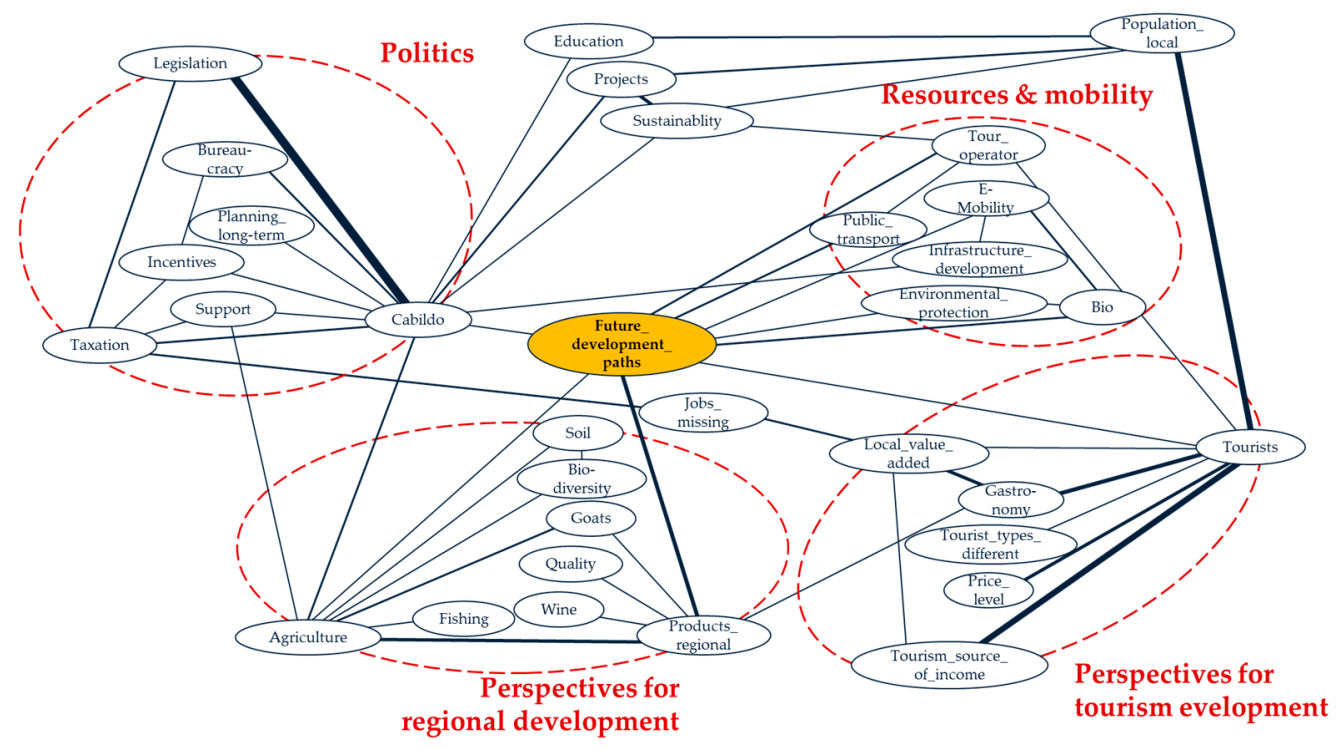

Figure 7. Network-graph “future development paths" (Source: own illustration, based on WinRelan ${ }^{\circledR}$ ).

Since the previous results showed critical discussions about the handling of the islands resources, strategic opportunities in this field are especially within the sphere of renewable energies, namely wind and solar energy, which are mostly available throughout the whole year. In a second step, these renewable resources seem helpful to develop offers in the area of e-mobility, both in private and public transport. Examples to be named here are e-bikes and electric car rentals on the private side, and an efficient public transport system based on renewable energies on the public side. Regarding such efforts, a crucial role lies with tour operators, who, according to the interviewees, should increase their commitment towards issues of resources and hence sustainable destination development.

"So if they want to use another energy, we have plenty of sun and light. We wouldn't really need the geothermic energy, because we have a lot of alternatives, but they keep depending on petrol." (Interviewee 7)

"If I were a politician, I would say: no gasoline cars any longer, only electric cars and public transport! There are no distances. You could organize the traffic network in a different way." (Interviewee 8)

Such efforts towards the use of more renewable energies can, in consequence, also have an influence on Lanzarote's tourism development. In this context, new target groups with a certain awareness for sustainability and who want to experience the island and its distinctive character consciously and outside of the aforementioned typical hotel resorts, can be attracted. This can take place, for example, via experiencing the local gastronomy in restaurants, which in the end can help to increase added value remaining directly on the island and, according to the interviewees, also generate new jobs. 
"I think the main thing is to improve the quality of tourism and to make sure that the tourists that come here are not just for one reason, but for many reasons. To sample the food, sample the culture, to do sports, go diving, take part in ironman, to do excursions. I think you want the tourist to be interested in all this. [ ... ] You need to diversify, you need to offer extra things." (Interviewee 3)

"It's a way to increase the expenditure, every day from each tourist. [ ... ] We consider we have margin to have a higher expenditure every day if the tourists want to taste everything, you know, go to La Geria, La Vegueta, to taste our gastronomy. Automatically, the expenditure every day is going to grow." (Interviewee 2)

With regard to regional development in the context of gastronomy and agricultural products, various prospects for future development paths can be identified, which can contribute to increased diversification with regard to both touristic offers and target groups. Due to the volcanic origin of Lanzarote, these paths arise, for example, from the special geological features and the resulting biodiversity, which form special conditions for farming fruits and vegetables, and from the field of stockbreeding.

Within this overall framework, policy plays a central role, as the primary task seems to be the creation of general conditions for sustainable destination and regional development through appropriate legislative design and observance. This goes along with a more long-term orientation of aspirations and the creation of concrete incentives for both companies and private actors. Among others, such incentives can be found in the establishment of cooperatives, but also in an attractive and, above all, transparent tax structure in order to increase the motivation for active participation in sustainable change.

"Big hotels mostly do not want these new activities because it is against their interests. The monopolies are directed against this type of privately-mediated tourism. The political instability, the constant change, is responsible for this and cannot develop a continuous model. Of all the positive upswing, only the rich ones profit. There is a lot of talk here about the legal discrepancies, but that's not true. We have laws that exist, but they are not applied in the right form. The law must run parallel to the political decisions." (Interviewee 4)

"Cooperative farmers bring their onions to the cooperative, but the Cabildo is hesitant about paying. That can be improved. If you pay the farmers punctually and quickly then they will start to cultivate again next year, but if you do not pay them, they will stop and you will not grow anymore. They say: What is that supposed to be? Why should I do that?" (Interviewee 6)

These challenges and future development paths in the context of the conducted research build the groundwork for the concept of alternative product development as an adjusted strategy, which can contribute to achieving sustainable tourism and improving destination development.

\section{Alternative Product Development: An Adjusted Strategy for Sustainable Tourism Development}

The empirical results underline that competitive and, at least in quantitative terms, successful destinations are not immune to current developments and challenges in tourism, as further studies recently also have described $[11,70,71]$. This can especially be stated for destinations focusing on the conventional tourist model, based on sun, sea and sand (the 3S), since a heavy focus on such a model fails to promote sustainability due to a lack in economic benefits for host communities as well as growing environmental pressures [72]. The result is a specific need for action, which has to be managed within the sphere of sustainable, holistic and intersectoral destination and regional development. However from a strategic point of view, this need for action does not mean giving up existing and 
successful considerations and business models in order to create completely new structures instead. Rather, additional strategies for diversification and thus sustainable destination development have to be formulated, from which appropriate measures can be derived. Based on, and supplementary to, the process of strategic product development, so-called alternative product development is identified as an additional strategy for diversification. The aim of the strategy of alternative product development lies therefore in the generation of a co-existence of both traditional and alternative products and offers., In this context, the latter have to go beyond established tourist models like the $3 \mathrm{~S}$ and need to be based on alternative values and themes that are characteristic for a destination, while of course maintaining the existing core products and offers, which contribute to the success and competitiveness of the destination, as the following Figure 8 underlines.

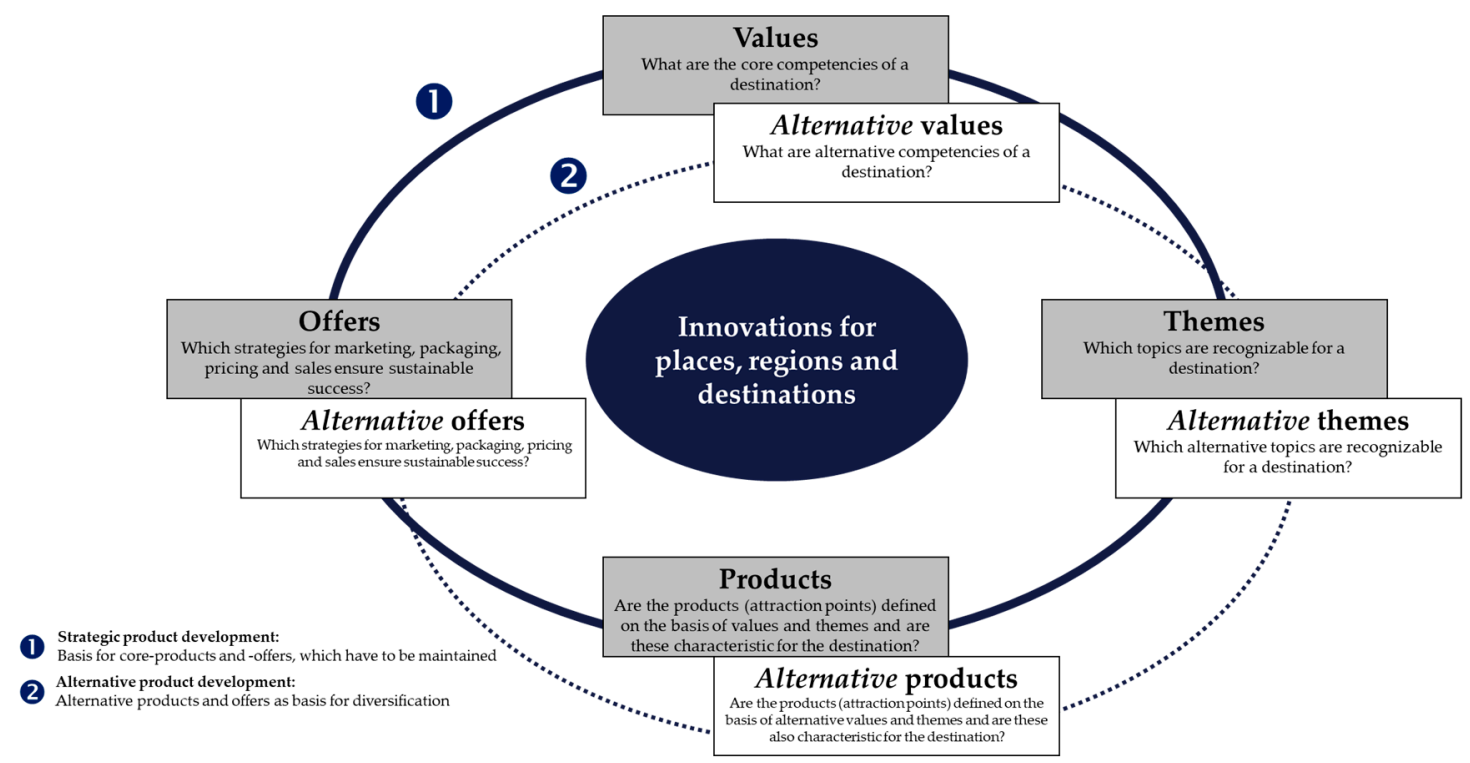

Figure 8. Alternative product development as a strategy towards sustainable tourism development (Source: Own illustration).

Considering alternative product development within the island of Lanzarote, a potential value can be found in the island's distinctive volcanic origin, from which island-specific themes related to geology and nature can be derived. In combination with the aspect of renewable energies, e-bike excursions within the Timanfaya National Park can be seen as a potential new product. Through appropriate marketing, this can either contribute to decreasing the concentration of tourists in hotel resorts along the coastline, or (in combination with other alternative products) even attract new, sustainability-oriented and potentially less price-sensitive target groups. This is especially important due to the fact that not only Lanzarote, but also many other, mostly European island destinations have for a long time been characterized by a large volume of aggressively sold package holidays [72]. In this context, literature suggests that within a destination, a growth of alternative tourism is likely to stimulate a decrease in package holidays [73].

This process of alternative product development as a supplement to already existing products and services represents an approach to overcome present challenges, especially in established destinations. With regard to the tourist area life cycle model [74,75], this strategy can be helpful for diversification not only, but above all, in mature destinations, which are facing an uncertain future and are therefore confronted with a need for action.

Within this process of alternative product development, it is important to mention that efforts in the context of sustainable development are considered to be most successful when they are driven endogenously by the local system [76], for example by regional entrepreneurs, but also by the local population and government. The government especially plays a crucial role in sustainable tourism 
development, since it has to implement long-term tourism policies and provide an overall direction and coordination [15]. This is especially true for tourism on islands like Lanzarote, since on islands the formulation of sustainable tourism policies and their implementation is often hindered by key players in the field of the government, political parties, local governments and communities [77]. Even though politics plays a central role here, alternative product development can only succeed in the context of a holistic and collaborative process, which includes all stakeholders involved in a destination's touristic system. Therefore, in addition to policy and the responsible destination management organization, the local population and involved companies on a regional (e.g., small and medium-sized enterprises like restaurants or family businesses) and international (such as hotel chains, tour operators or mobility service providers) scale also need to be mentioned as relevant stakeholders.

Even though they are usually not directly involved in the development of touristic offers, the tourists visiting a destination play an important role in the course of tourism development as well. This makes them relevant stakeholders within the tourism system, as is demonstrated via their contribution to a local tourism system prior to a journey (e.g., through demand behavior) and throughout the stay in the destination (e.g., through socio-spatial behavior). Therefore, both demand for different products or services and a changed socio-spatial behavior can influence the impacts of tourism and, in consequence, its perception within the destination. Subsequently and in addition to the stakeholder groups presented in Section two, tourists can be added as a sixth stakeholder group in the field of sustainable development.

With regard to the central question raised in the beginning of the article, the study has been able to identify alternative product development as a new strategy, which can be pursued on a destination level in addition to existing strategies and tourist models. It is important to emphasize that this strategy has no universal character that can applied to any destination. Rather it is important to view this strategy from the lens of specific and endogenous values and structure that shape a certain destination. If destinations succeed in combining existing strategies and tourist models with alternative approaches, the presented strategy can be helpful on the way to a more sustainable tourism development, which is currently more than ever before at stake.

\section{Conclusions}

The prevailing research demonstrated that established destinations like Lanzarote are not immune to the current changes and challenges in tourism and are therefore confronted with a certain need for action. In this context, the current success of a destination threatens to become a challenge in the long run, if negative consequences resulting from tourism development are not managed in an equally active and sustainability-oriented way. Within this, it is important to emphasize that successful and established strategies and business models within a destination do not have to be completely replaced by others; indeed, it is the former that laid the foundation for long-term success and positive destination and regional development. At the same time and against the background of current developments and challenges, it is important to consciously deal with complementary strategies that are able to shape destination development sustainably and in the best case even resiliently. This results in a need for action, which should be addressed in the context of stronger diversification regarding both target groups and products in order to initiate a more sustainable destination and regional development. In this field, the study was able to identify the process of alternative product development, which was derived from, and acts as a supplement to, the process of strategic product development. By using the special case of Lanzarote, it can be stated that this process can be seen as a new strategy for not only, but above all, more sustainable development established destinations.

Limitations of the study can on the one hand be seen in the size of the sample, which seems to be a result of the fact that the topic per se is a sensitive one, and which might be supplemented by increasingly intensified discussions about negative effects of tourism at the time of the survey. In addition, the researchers' lack of direct access to the study area in the run-up to the empirical research has to be mentioned; one way of enhancing the reliability of the results would be to integrate a second 
survey period, which is based on the first one and conducted according to the principles of the snowball system. On the other hand, there is a limitation in the spatially clearly delimitable research area within a singular destination, which is further reinforced by the status of Lanzarote as an island.

Against this background, future research could conduct a similar study in a destination located in the continental mainland, since island destinations like Lanzarote are subject to special framework conditions. From a structural perspective, further research may analyze the process of alternative product development in island destinations with different business models that are not so much based on the existence and presence of international tour operators and hotel chains.

Author Contributions: Conceptualization, C.E.; Investigation, C.E. and H.P.; Methodology, C.E.; Project administration, C.E. and H.P.; Supervision, H.P.; Visualization, C.E.; Writing-original draft, C.E.; Writing-review \& editing, H.P.

Funding: This research received no external funding.

Acknowledgments: The research took place during a field visit on Lanzarote with students from the Master's program "Tourism and Regional Planning" at the Catholic University of Eichstaett-Ingolstadt. After this field visit, the students contributed in the preparations of the empirical analysis. The authors would like to thank: Susann Bauer, Katharina Biermann, Constanze Boll, Benjamin Gatzer, Valentin Herbold, Hannah Hochberger, Markus Kantsperger, Eva Lill, Beatrix Loidl, Kathrin Ortlieb, Maren Schlichtholz \& Stefan Sowa.

Conflicts of Interest: The authors declare no conflict of interest.

\section{References}

1. Pechlaner, H.; Tretter, M. Von der Kernkompetenz zum Produkt-Innovationen in Destinationen durch Strategische Produktentwicklung. In Kulturtourismus zu Beginnn des 21. Jahrhunderts; Quack, H.-D., Klemm, C., Eds.; Oldenbourg: München, Germany, 2013; pp. 105-115.

2. Blanco-Romero, A.; Blázquez-Salom, M.; Cànoves, G. Barcelona, Housing Rent Bubble in a Tourist City. Social Responses and Local Policies. Sustainability 2018, 10, 2043. [CrossRef]

3. Cheng, M. Current sharing economy media discourse in tourism. Ann. Tour. Res. 2016, 60, 111-114. [CrossRef]

4. Forno, F.; Garibaldi, R. Sharing Economy in Travel and Tourism: The Case of Home-Swapping in Italy. J. Qual. Assur. Hosp. Tour. 2015, 16, 202-220. [CrossRef]

5. Hall, C.M. On the mobility of tourism mobilities. Curr. Issues Tour. 2015, 18, 7-10. [CrossRef]

6. Joppe, M. Tourism policy and governance: Quo vadis? Tour. Manag. Perspect. 2018, 25, 201-204. [CrossRef]

7. Salvioni, D. Hotel Chains and the Sharing Economy in Global Tourism. Symph. Emerg. Issues Manag. 2016, 1, 31-44.

8. Signorile, P.; Larosa, V.; Spiru, A. Mobility as a service: A new model for sustainable mobility in tourism. Worldw. Hosp. Tour. Themes 2018, 10, 185-200. [CrossRef]

9. Zervas, G.; Proserpio, D.; Byers, J.W. The Rise of the Sharing Economy: Estimating the Impact of Airbnb on the Hotel Industry. J. Mark. Res. 2017, 54, 687-705. [CrossRef]

10. Von Bergner, N.M.; Lohmann, M. Future Challenges for Global Tourism: A Delphi Survey. J. Travel Res. 2014, 53, 420-432. [CrossRef]

11. Eckert, C.; Zacher, D.; Pechlaner, H.; Namberger, P.; Schmude, J. Strategies and measures directed towards overtourism: A perspective of European DMOs. Int. J. Tour. Cities 2019. [CrossRef]

12. Herntrei, M. Wettbewerbsfähigkeit von Tourismusdestinationen: Bürgerbeteiligung als Erfolgsfaktor? Springer: Wiesbaden, Germany, 2014.

13. Benur, A.M.; Bramwell, B. Tourism product development and product diversification in destinations. Tour. Manag. 2015, 50, 213-224. [CrossRef]

14. Bramwell, B. Mass Tourism, Diversification and Sustainability in Southern Europe's Coastal Regions. In Coastal Mass Tourism: Diversification and Sustainable Development in Southern Europe; Bramwell, B., Ed.; Channel View: Bristol, UK, 2004; pp. 1-31.

15. Nunkoo, R. Tourism development and trust in local government. Tour. Manag. 2015, 46, 623-634. [CrossRef]

16. Jimenez, F.; García Quesada, M.; Villoria, M. Corruption in Paradise: The puzzling case of Lanzarote (Canary Islands, Spain). XXII Pisa World Congress of Political Science. 9 July 2012. Available online: https://www.researchgate.net/publication/266323816_Corruption_in_Paradise_the_puzzling_case_ of_Lanzarote_Canary_Islands_Spain (accessed on 14 June 2019). 
17. Santana-Talavera, A.; Fernández-Betancort, H. Times of Tourism: Development and Sustainability in Lanzarote, Spain. In Tourism as an Instrument for Development: A Theoretical and Pracitcal Study; Fayos-Solà, E., Ed.; Emerald: Bingley, UK, 2014; pp. 241-264.

18. Canary Islands: Tourist Arrivals. Historical Data: 1997-2018. Available online: https://turismodeislascanarias. com/sites/default/files/promotur_serie_frontur_1997-2018_en.pdf (accessed on 13 June 2019).

19. Canary Islands: Lanzarote: Profile of Tourists. Available online: https://turismodeislascanarias.com/sites/ default/files/promotur_visita_mas_de_una_isla_lanzarote_2017_en.pdf (accessed on 13 June 2019).

20. Wang, S.; Chen, J.S. The influence of place identity on perceived tourism impacts. Ann. Tour. Res. 2015, 52, 16-28. [CrossRef]

21. Alam, M.S.; Paramati, S.R. The impact of tourism on income inequality in developing economies: Does Kuznets curve hypothesis exist? Ann. Tour. Res. 2016, 61, 111-126. [CrossRef]

22. García, F.A.; Vázquez, A.B.; Macías, R.C. Resident's attitudes towards the impacts of tourism. Tour. Manag. Perspect. 2015, 13, 33-40. [CrossRef]

23. Andereck, K.L.; Valentine, K.M.; Knopf, R.C.; Vogt, C.A. Residents' perceptions of community tourism impact. Ann. Tour. Res. 2005, 32, 1056-1076. [CrossRef]

24. Archer, L.; Cooper, C.; Ruhanen, L. The positive and negative impacts of tourism. In Global Tourism; Theobald, W.F., Ed.; Routledge: London, UK, 2012; pp. 79-102.

25. Boley, B.B.; McGehee, N.G.; Perdue, R.R.; Long, P. Empowerment and resident attitudes toward tourism: Strengthening the theoretical foundation through a Weberian lens. Ann. Tour. Res. 2014, 49, 3-50. [CrossRef]

26. Kim, K.; Uysal, M.; Sirgy, M.J. How does tourism in a community impact the quality of life of community residents? Tour. Manag. 2013, 36, 527-540. [CrossRef]

27. Nunkoo, R.; Gursoy, D. Residents' support for tourism. An Identity Perspective. Ann. Tour. Res. 2012, 39, 243-268. [CrossRef]

28. Sharpley, R. Host perceptions of tourism: A review of the research. Tour. Manag. 2014, 42, 37-49. [CrossRef]

29. Zolfani, S.M.; Sedaghat, M.; Maknoon, R.; Zavadskas, E.K. Sustainable tourism: A comprehensive literature review on frameworks and applications. Econ. Res. Ekon. Istraživanja 2015, 28, 1-30. [CrossRef]

30. Juvan, E.; Dolnicar, S. Measuring environmentally sustainable tourist behaviour. Ann. Tour. Res. 2016, 59, 30-44. [CrossRef]

31. Ali, A.; Frew, A.J. ICT and sustainable tourism development: An innovative perspective. J. Hosp. Tour. Technol. 2014, 5, 2-16. [CrossRef]

32. Canavan, B. Sustainable tourism: Development, decline and de-growth. Management issues from the Isle of Man. J. Sustain. Tour. 2014, 22, 127-147. [CrossRef]

33. Ritchie, J.R.B.; Crouch, G.I. The Competitive Destination: A Sustainable Tourism Perspective; Oxford University Press: Oxford, UK, 2005.

34. Muresan, I.C.; Oroian, C.F.; Harun, R.; Arion, F.H.; Porutiu, A.; Chiciudean, G.O.; Todea, A.; Lile, R. Local Residents' Attitude toward Sustainable Rural Tourism Development. Sustainability 2016, 8, 100. [CrossRef]

35. Torres-Delgado, A.; Palomeque, F.L. Measuring sustainable tourism at the municipal level. Ann. Tour. Res. 2014, 49, 122-137. [CrossRef]

36. World Commission on Environment and Development. Our Common Future; Oxford University Press: New York, NY, USA, 1987.

37. Loorbach, D.; Shiroyama, H. The Challenge of Sustainable Urban Development and Transforming Cities. In Governance of Urban. Sustainability Transitions: European and Asian Experience; Loorbach, D., Wittmayer, J.M., Shiroyama, H., Fujino, J., Mizuguchi, S., Eds.; Springer: Tokyo, Japan; Heidelberg, Germany; New York, NY, USA; Dordrecht, The Netherlands; London, UK, 2016; pp. 3-12.

38. Edgell, D.L. Managing Sustainable Tourism: A Legacy for the Future; Routledge: London, UK, 2016.

39. Butler, R.W. Sustainable tourism: A state-of-the-art review. Tour. Geogr. 1999, 1, 7-25. [CrossRef]

40. Jovicic, Z.V. Key issues in the implementation of sustainable tourism. Curr. Issues Tour. 2014, 17, $297-302$. [CrossRef]

41. Torres-Delgado, A.; Saarinen, J. Using indicators to assess sustainable tourism development: A review. Tour. Geogr. 2014, 16, 31-47. [CrossRef]

42. Stoddard, J.E.; Pollard, C.E.; Evans, M.R. The Triple Bottom Line: A Framework for Sustainable Tourism Development. Int. J. Hosp. Tour. Adm. 2012, 13, 233-258. [CrossRef] 
43. Tyrrell, T.; Paris, C.M.; Biaett, V. A Quantified Triple Bottom Line for Tourism: Experimental Results. J. Travel Res. 2012, 52, 279-293. [CrossRef]

44. Dwyer, L. Relevance of triple bottom line reporting to achievement of sustainable tourism: A scoping study. Tour. Rev. Int. 2005, 9, 79-83. [CrossRef]

45. Poudel, S.; Nyaupane, G.P.; Budruk, M. Stakeholders' Perspectives of Sustainable Tourism Development: A New Approach to Measuring Outcomes. J. Travel Res. 2016, 55, 465-480. [CrossRef]

46. World Tourism Organization International Network of Sustainable Tourism Observatories. Available online: http://insto.unwto.org/about/ (accessed on 17 May 2019).

47. Byrd, E.T. Stakeholders in sustainable tourism development and their roles: Applying stakeholder theory to sustainable tourism development. Tour. Rev. 2007, 62, 6-13. [CrossRef]

48. Waligo, V.M.; Clarke, J.; Hawkins, R. Implementing sustainable tourism: A multistakeholder involvement management framework. Tour. Manag. 2013, 36, 342-353. [CrossRef]

49. Friedman, A.; Miles, S. Developing stakeholder theory. J. Manag. Stud. 2002, 39, 1-21. [CrossRef]

50. Lyon, A.; Hunter-Jones, P.; Warnaby, G. Are we any closer to sustainable development? Listening to active stakeholder discourses of tourism development in the Waterberg Biosphere Reserve, South Africa. Tour. Manag. 2017, 61, 234-247. [CrossRef]

51. Getz, D.; Timur, S. Stakeholder involvement in sustainable tourism: Balancing the voices. In Global Tourism; Theobald, W.F., Ed.; Routledge: London, UK, 2012; pp. 230-247.

52. Jamal, T.; Stronza, A. Collaboration theory and tourism practice in protected areas: Stakeholders, structuring and sustainability. J. Sustain. Tour. 2009, 17, 169-189. [CrossRef]

53. Ruhanen, L. Local government: Facilitator or inhibitor of sustainable tourism development? J. Sustain. Tour. 2013, 21, 80-98. [CrossRef]

54. Sautter, E.T.; Leisen, B. Managing Stakeholders. A Tourism Planning Model. Ann. Tour. Res. 1999, 26, 312-328. [CrossRef]

55. Miller, G.; Twining-Ward, L. Monitoring for a Sustainable Tourism Transition: The Challenge of Developing and Using Indicators; CABI: Wallingford, UK, 2005.

56. Zhu, H.; Liu, J.; Wei, Z.; Li, W.; Wang, L. Residents' Attitudes towards Sustainable Tourism Development in a Historical-Cultural Village: Influence of Perceived Impacts, Sense of Place and Tourism Development Potential. Sustainability 2017, 9, 61. [CrossRef]

57. Sánchez Cañizares, S.M.; Castillo Canalejo, A.M.; Núñez Tabales, J.M. Stakeholders' perceptions of tourism development in Cape Verde, Africa. Curr. Issues Tour. 2016, 19, 966-980. [CrossRef]

58. Stylidis, D.; Belhassen, Y.; Shani, A. Three Tales of a City: Stakeholders' Images of Eilat as a Tourist Destination. J. Travel Res. 2015, 54, 702-716. [CrossRef]

59. Collis, D.J.; Montgomery, C.A. Competing on resources: Strategy in the 1990's. Harv. Bus. Rev. 1995, 73, 118-128.

60. Denicolai, S.; Cioccarelli, G.; Zucchella, A. Resource-based local development and networked core-competencies for tourism excellence. Tour. Manag. 2010, 31, 260-266. [CrossRef]

61. Flagestadt, A.; Hope, C.A. Strategic success in winter sports destinations: A sustainable value creation perspective. Tour. Manag. 2001, 22, 445-461. [CrossRef]

62. Pikkemaat, B.; Peters, M.; Chan, C.-S. Needs, drivers and barriers of innovation: The case of an alpine community-model destination. Tour. Manag. Perspect. 2018, 25, 53-63. [CrossRef]

63. Haugland, S.A.; Ness, H.; Grønseth, B.-O.; Aarstad, J. Development of Tourism Destinations. An Integrated Multilevel Perspective. Ann. Tour. Res. 2011, 38, 268-290. [CrossRef]

64. Pechlaner, H.; Fischer, E.; Hammann, E.-M. Leadership and Innovation Processes-Development of Products and Services Based on Core Competenies. J. Qual. Assur. Hosp. Tour. 2006, 6, 31-57. [CrossRef]

65. Alonso, A.D. Exploring a developing tourism industry: A resource-based view approach. Tour. Recreat. Res. 2017, 42, 45-58.

66. Pechlaner, H.; Hammann, E.-M.; Fischer, E. Leadership und Innovationsprozesse. Von der Kernkompetenz zur Dienstleistung. In Erfolg durch Innovation: Perspektiven Für den Tourismus- und Dienstleistungssektor; Pechlaner, H., Tschurtschenthaler, P., Peters, M., Pikkemaat, B., Fuchs, M., Eds.; Deutscher Universitäts-Verlag: Wiesbaden, Germany, 2005; pp. 63-87. 
67. Pechlaner, H.; Fischer, E.; Hammann, E.-M. Innovationen in Standorten-Perspektiven für den Tourismus. In Strategische Produktentwicklung im Standortmanagement: Wettbewerbsvorteile für den Tourismus; Pechlaner, H., Fischer, E., Eds.; Erich-Schmidt-Verlag: Berlin, Germany, 2009; pp. 9-29.

68. Zelger, J.; Lösch, H. Formale und semantische Folgen der Komplexitätsreduktion von

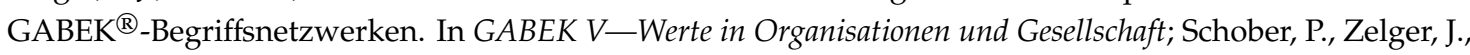
Raich, M., Eds.; Studien Verlag: Innsbruck, Austria, 2012; pp. 81-103.

69. Pechlaner, H.; Volgger, M. How to promote cooperation in the hospitality industry-Generating practitioner relevant knowledge using the GABEK qualitative research strategy. Int. J. Contemp. Hosp. Manag. 2012, 24, 925-945. [CrossRef]

70. Martin, B.S.; Uysal, M. An examination of the relationship between carrying capacity and the tourism lifecycle: Management and policy implications. J. Environ. Manag. 1990, 31, 327-333. [CrossRef]

71. Seraphin, H.; Sheeran, P.; Pilato, M. Over-tourism and the fall of Venice as a destination. J. Destin. Mark. Manag. 2018, 9, 374-376. [CrossRef]

72. Spilanis, I.; Vayanni, H. Sustainable Tourism: Utopia or Necessity? The Role of New Forms of Tourism in the Aegean Islands. In Coastal Mass Tourism. Diversification and Sustainable Development in Southern Europe; Bramwell, B., Ed.; Channel View: Bristol, UK, 2004; pp. 269-291.

73. Sadler, J. Sustainable Tourism Planning in Northern Cyprus. In Coastal Mass Tourism. Diversification and Sustainable Development in Southern Europe; Bramwell, B., Ed.; Channel View: Bristol, UK, 2004; pp. 133-156.

74. Butler, R.W. The concept of a tourist area cycle of evolution: Implications for management of resources. Can. Geogr. 1980, 24, 5-12. [CrossRef]

75. Butler, R.W. The Tourism Area Life Cycle: Conceptual and Theoretical Issues; Channel View: Clevedon, UK; Buffalo, NY, USA; Toronto, ON, Canada, 2006.

76. Roberts, L. Capital accumulation: Tourism and development processes in Central and Eastern Europe. In Tourism and Transition: Governance, Transformation and Development; Hall, D., Ed.; CABI: Wallingford, UK, 2004; pp. 53-64.

77. Yasarata, M.; Altinay, L.; Burnes, P.; Okumus, F. Politics and sustainable tourism development-Can they co-exist? Voices from North Cyprus. Tour. Manag. 2010, 31, 345-356. [CrossRef]

(C) 2019 by the authors. Licensee MDPI, Basel, Switzerland. This article is an open access article distributed under the terms and conditions of the Creative Commons Attribution (CC BY) license (http://creativecommons.org/licenses/by/4.0/). 